\title{
Transforming growth factor- $\beta$ (TGF- $\beta$ ) maintains follicular ultrastructure and stimulates preantral follicle growth in caprine ovarian tissue cultured in vitro
}

[Fator de crescimento transformante- $\beta(T G F-\beta)$ mantém a ultraestrutura folicular e estimula o crescimento de folículos pré-antrais caprinos inclusos em tecido ovariano cultivado in vitro]

G.Q. Rodrigues ${ }^{1}$, I.M.T. Lima $^{1}$, R.N. Chaves $^{1}$, R. Rossetto ${ }^{1}$, S.L. Costa ${ }^{2}$, S.V. Castro ${ }^{1}$, V.R.P. Barros ${ }^{3}$, M.H.T. Matos ${ }^{3}$, C.A.P. Lopes ${ }^{1}$, S.N. Báo ${ }^{4}$, C.C. Campello ${ }^{1}$, J.R. Figueiredo ${ }^{1}$

\author{
${ }^{1}$ Faculdade de Veterinária - Universidade de Ceará - Fortaleza, CE \\ ${ }^{2}$ Faculdade de Veterinária - Universidade de Viçosa - Viçosa, MG \\ ${ }^{3}$ Universidade Federal do Vale do São Francisco - UNIVASF - Petrolina, PE \\ ${ }^{4}$ Instituto de Biologia - Universidade de Brasília - Brasília, DF
}

\begin{abstract}
The objectives of this study were to investigate whether TGF- $\beta$ affect the survival, activation and further growth of goat primordial follicles enclosed in ovarian cortex after in vitro culture. Goat ovaries were collected from an abattoir and pieces of ovarian tissues were cultured for one or seven days in a supplemented alpha Minimum Essential Medium, alone or containing TGF- $\beta$ (1, 5, 10 or 50ng/mL). Ovarian tissues from the fresh control as well as those cultured were processed for histological and ultrastructural studies. The results showed that when compared with fresh control, there was decrease in the percentages of histologically normal follicles in all treatments only after seven days culture. TGF- $\beta$ did not affect the activation of preantral follicles regardless of its concentration, however, larger follicles diameter $(\mathrm{P}<0.05)$ was observed using $10 \mathrm{ng} / \mathrm{mL}$ TGF- $\beta$ than in the fresh control and other treatments. Moreover, this concentration maintained the normal ultrastructure after seven days of culture. In conclusion, TGF- $\beta$ showed additional effect on the follicle growth and the maintenance of ultrastructural integrity of goat preantral follicles enclosed in ovarian tissue when used at $10 \mathrm{ng} / \mathrm{mL}$ during seven days of culture.
\end{abstract}

Keywords: goat, preantral follicle, in vitro development, TGF- $\beta$

\section{RESUMO}

O objetivo desse estudo foi investigar se o TGF- $\beta$ afeta a sobrevivência, ativação e crescimento de folículos primordiais caprinos inclusos no córtex ovariano após o cultivo in vitro. Ovários de cabras foram coletados em abatedouro e fragmentos de tecido ovariano foram cultivados por um e sete dias em meio essencial mínimo alfa $\left(\alpha-M E M^{+}\right)$sozinho ou suplementado com TGF- $\beta$ (1, 5, 10 ou 50ng/mL). Fragmentos ovarianos não cultivados e cultivados foram processados para análise histológica $e$ ultraestrutural. Os resultados mostraram que, comparado ao controle fresco, houve diminuição no percentual de folículos morfologicamente normais em todos os tratamentos somente após sete dias de cultivo. O TGF- $\beta$ não afetou a ativação folicular independente da concentração testada, contudo, o diâmetro folicular foi superior $(P<0.05)$ no tratamento com $10 \mathrm{ng} / \mathrm{mL}$ de $T G F-\beta$ quando comparado ao controle fresco e aos demais tratamentos. Além disso, essa mesma concentração manteve a ultraestrutura normal dos folículos após sete dias de cultivo. Em conclusão, o TGF- $\beta$ apresentou efeito adicional no crescimento folicular e na manutenção da integridade ultraestrutural de folículos pré-antrais caprinos inclusos no tecido ovariano quando utilizado na concentração de $10 \mathrm{ng} / \mathrm{mL}$ durante sete dias de cultivo.

Palavras-chave: cabra, folículo pré-antral, desenvolvimento in vitro, TGF- $\beta$

Recebido em 1 de agosto de 2012

Aceito em 20 de junho de 2013

E-mail: gqrvet@hotmail.com 


\section{INTRODUCTION}

The transforming growth factor- $\beta$ (TGF- $\beta$ ) is a polypeptide belonging to the TGF- $\beta$ superfamily and produced by several cell types, mainly $\mathrm{T}$ cells (Knight and Glister, 2006). This factor acts through serine-threonine kinase receptors classified into type I (TGF $\beta$ RI) and type II (TGF $\beta$ RII). In the ovary, TGF- $\beta$ and its receptors have been identified in the granulosa and theca cells in cattle (Zheng et al., 2008), sheep (Er-lin et al., 2010) and murine (Hernandez et al., 1990). Its effects on folliculogenesis are contradictory, since this substance has been described as suppressive and stimulant of the proliferation of granulosa cells and theca cells according to the species, stage of differentiation and presence of other growth factors (Roberts and Skinner, 1991). In buffaloes, TGF- $\beta$ associated with TGF- $\alpha$ increased DNA fragmentation and inhibited follicular growth and survival (Sharma et al., 2010). In contrast, in murines, TGF- $\beta$ increased the granulosa cell proliferation and improved aromatase activity and progesterone synthesis (Roy, 1993). In caprines, the effects of this growth factor on the viability and development of preantral follicles cultured in vitro are still unknown. Thus, the aim of this study was to investigate whether TGF- $\beta$ affects the survival, activation and growth of in vitro cultured goat primordial follicles enclosed in ovarian cortex.

\section{MATERIAL AND METHODS}

For this purpose, 10 ovaries from adult goats were collected and transported at $4^{\circ} \mathrm{C}$ to the laboratory. Thereafter, tissue samples from each ovarian pair were cut into 13 slices, which were then either directly fixed for histological and ultrastructural analyses (fresh control) or placed in culture for one or seven days. Culture was performed in 24-well culture dishes containing $1 \mathrm{~mL}$ of culture media at $39{ }^{\circ} \mathrm{C}$ in $5 \% \mathrm{CO}_{2}$ in a humidified incubator. The basic culture medium (cultured control) consisted of $\alpha$-MEM supplemented with ITS $(10 \mu \mathrm{g} / \mathrm{mL}$ insulin, $5.5 \mu \mathrm{g} / \mathrm{mL}$ transferrin, and $5 \mathrm{ng} / \mathrm{mL}$ selenium), $2 \mathrm{mM}$ glutamine, $2 \mathrm{mM}$ hipoxanthine, $50 \mu \mathrm{g} / \mathrm{mL}$ ascorbic acid and $1.25 \mathrm{mg} / \mathrm{mL}$ bovine serum albumin (BSA), which was called $\alpha-\mathrm{MEM}^{+}$. For the experimental conditions, the medium was supplemented with TGF- $\beta$ at different concentrations $(1,5,10$ or $50 \mathrm{ng} / \mathrm{mL})$. Each treatment was repeated five times and the culture media was replenished every other day.

Before culture (fresh control) and after one or seven days in culture, all the pieces were fixed in Carnoy's solution for $12 \mathrm{~h}$ and then dehydrated and processed for histological analysis as previously described (Celestino et al., 2011). Follicle stage and survival were assessed microscopically on serial sections. Coded anonymized slides were examined on a microscopy (Nikon, Japan) under 400X magnification. The developmental stages of preantral follicles were defined as primordial or growing follicles (intermediate, primary and secondary). These follicles were also classified as histologically normal or degenerate based on the features of oocyte and granulosa cells (Celestino et al., 2011). Overall, 150 preantral follicles were evaluated for each treatment. To evaluate follicular activation, the percentages of healthy primordial and growing follicles were calculated before (fresh control) and after culture in each medium. In addition, follicle and oocyte diameters were measured only in healthy follicles (Celestino et al., 2011). Care was taken to count each follicle only once as we have also done in our earlier studies (Matos et al., 2007).

To better evaluate follicular morphology, ultrastructural analysis was performed on preantral follicles from the fresh control, follicles cultured in $\alpha-\mathrm{MEM}^{+}$alone, and follicles cultured in $\alpha-\mathrm{MEM}^{+}$supplemented with $10 \mathrm{ng} / \mathrm{mL}$ TGF- $\beta$, because this treatment had the best results on follicle growth. Small pieces $\left(1 \mathrm{~mm}^{3}\right)$ of ovarian tissues were fixed and processed for ultrastructural analysis according to Celestino et al. (2011). Parameters such as density and integrity of ooplasmic and granulosa cell organelles, vacuolization and basement membrane integrity were evaluated.

Percentages of morphologically normal, primordial and growing follicles after one or seven days of culture were initially submitted to Shapiro-Wilk and Bartlett tests to confirm a normal distribution and homogeneity of variance, respectively. Analysis of variance (ANOVA) was then carried out using GLM procedure of SAS (1999), and a Dunnett test was applied for the comparison of each treatment tested against control groups $\left(\right.$ Control and $\left.\alpha-\mathrm{MEM}^{+}\right)$. Student Newman Keuls (SNK) test was used to evaluate 
the effects of different concentrations of TGF- $\beta$. Results were expressed as mean \pm SD and differences were considered to be significant when $\mathrm{P}<0.05$.

\section{RESULTS}

Regarding the follicular survival, a significant decrease $(\mathrm{P}<0.05)$ in the percentages of histologically normal follicles was observed only after seven days culture in all treatments when compared with the fresh control. No significant differences $(\mathrm{P}>0.05)$ were observed after one or seven days of culture among treatments. Concerning follicular activation, the percentages of growing follicles in the fresh control was
$48.51 \%$. In all groups, there was no significant reduction $(\mathrm{P}>0.05)$ in primordial follicles concomitant with an increase of growing follicles.

The diameters of follicles and oocytes before (fresh control) and after one or seven days of culture are shown in Table 1. After one and seven days of culture, a significant increase $(\mathrm{P}<0.05)$ in follicle diameter was observed in medium containing $10 \mathrm{ng} / \mathrm{mL}$ TGF- $\beta$ when compared with control and other treatments. Concerning oocyte diameter, no significant differences were observed among all groups (cultured and non-cultured tissues), regardless of the treatment and culture period.

Table 1. Follicle and oocyte diameters (mean \pm SEM) in noncultured tissues and in tissues cultured for one or seven days in $\alpha$-MEM + and $\alpha$-MEM+ supplemented with various concentrations of TGF- $\beta$. Per treatment 150 follicles were evaluated.

\begin{tabular}{|c|c|c|}
\hline & Follicle diameter $(\mu \mathrm{m})$ & Oocyte diameter $(\mu \mathrm{m})$ \\
\hline Fresh control (day 0) & $34.57 \pm 8.32$ & $25.34 \pm 7.80$ \\
\hline \multicolumn{3}{|l|}{ Cultured (day 1) } \\
\hline$\alpha-$ MEM $^{+}$ & $33.23 \pm 4.81^{b}$ & $23.77 \pm 4.77$ \\
\hline TGF- $\beta$ 1ng/mL & $33.04 \pm 7.07^{\mathrm{b}}$ & $22.12 \pm 2.90$ \\
\hline TGF- $\beta$ 5ng/mL & $32.98 \pm 3.77^{\mathrm{b}}$ & $22.59 \pm 2.64$ \\
\hline TGF- $\beta$ 10ng/mL & $36.64 \pm 5.46^{* a}$ & $24.85 \pm 2.80$ \\
\hline TGF- $\beta$ 50ng/mL & $33.68 \pm 4.00^{\mathrm{b}}$ & $23.82 \pm 2.92$ \\
\hline \multicolumn{3}{|l|}{ Cultured (day 7) } \\
\hline$\alpha-\mathrm{MEM}^{+}$ & $29.02 \pm 13.93^{\mathrm{b}}$ & $20.86 \pm 7.80$ \\
\hline TGF- $\beta$ 1ng/mL & $34.49 \pm 4.66^{\mathrm{b}}$ & $24.91 \pm 3.57$ \\
\hline TGF- $\beta$ 5ng/mL & $33.80 \pm 2.51^{b}$ & $24.19 \pm 2.51$ \\
\hline TGF- $\beta$ 10ng/mL & $37.13 \pm 3.49 * \mathrm{a}$ & $25.63 \pm 2.62$ \\
\hline TGF- $\beta$ 50ng/mL & $32.38 \pm 4.22^{\mathrm{b}}$ & $22.52 \pm 3.41$ \\
\hline
\end{tabular}

Different letters in the same column denote significant differences among treatments within the same period $(\mathrm{P}<0.05)$. * $\mathrm{P}<0.05$, significantly different from the fresh control (Day 0 ). 


\section{Rodrigues et al.}

For a better evaluation of follicular integrity, ultrastructural analysis was performed on preantral follicles from the fresh control and in those cultured for seven days in $\alpha-\mathrm{MEM}^{+}$alone or containing $10 \mathrm{ng} / \mathrm{mL}$ TGF- $\beta$. Ultrastructural features of follicles evaluated in the fresh control (Figure 1A) and 10ng/mL TGF- $\beta$ (Figure 1B) showed intact oocyte and granulosa cell membranes and large oocyte nuclei. Organelles were uniformly distributed in the ooplasm, especially mitochondria and endoplasmic reticulum. In addition, granulosa cells were ultrastructurally normal, showing an elongated and large nucleus with an irregular membrane and a high proportion of nucleus to cytoplasm. Nevertheless, follicles cultured for seven days in $\alpha-\mathrm{MEM}^{+}$(Figure 1C) showed signs of degeneration, such as high levels of cytoplasmic vacuolization, absence of integrity in the basal membrane, and disorganized granulosa cells.
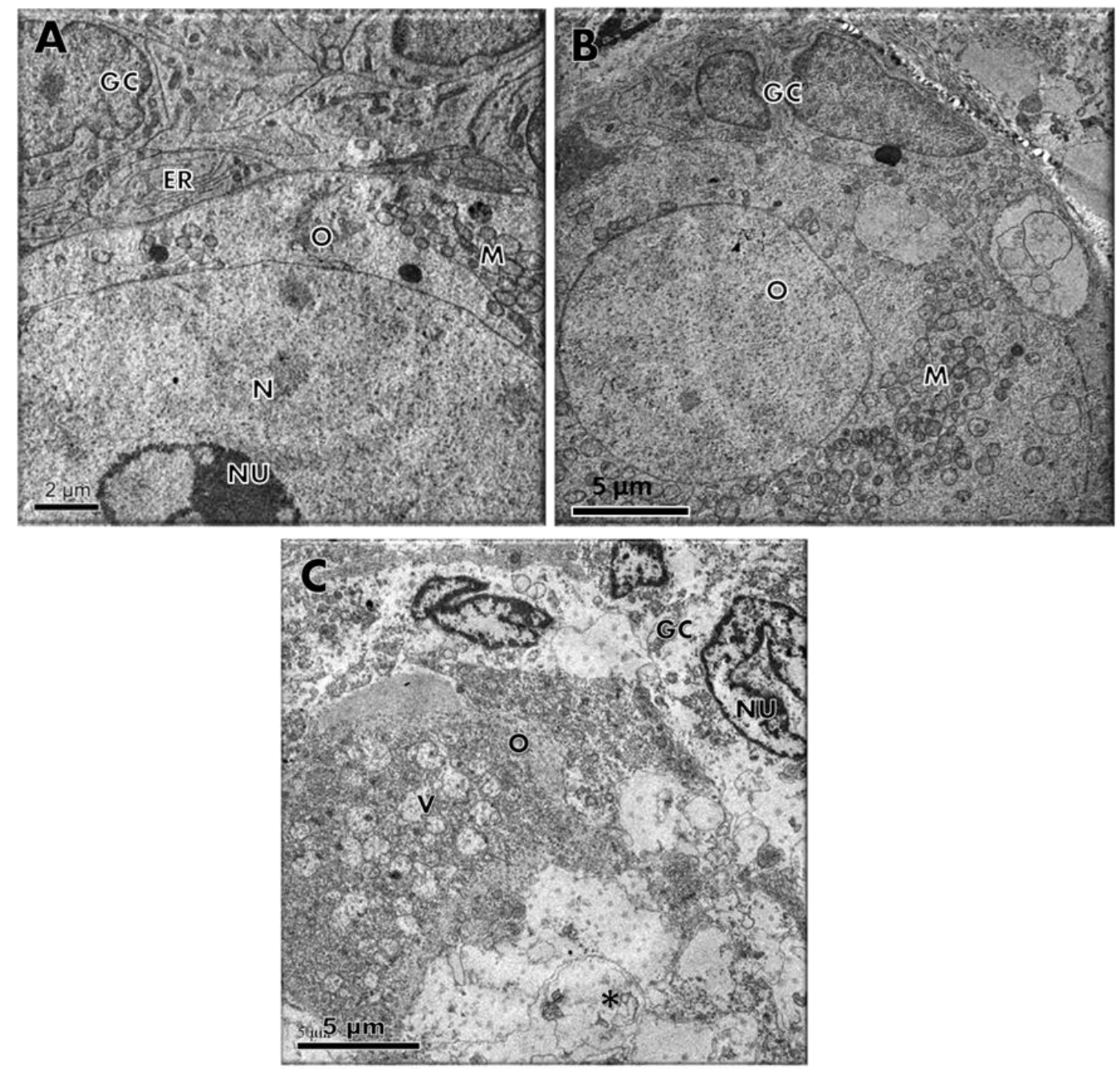

Figure 1. (A) Electron micrograph of a non-cultured preantral follicle (fresh control). Note the great nucleus to cytoplasm ratio in granulosa cells. N: nucleus; NU: nucleolus; O; oocyte; GC: granulosa cells; M: mitochondria; ER: endoplasmic reticulum; Bar: $2 \mu \mathrm{m}$. (B) Electron micrograph of a preantral follicle cultured for seven days in $\alpha-M E M+$ supplemented with $10 \mathrm{ng} / \mathrm{mL}$ TGF- $\beta$. Note the great nuclear to cytoplasm ratio in granulosa cells. N: nucleus; O; oocyte; GC: granulosa cells; M: mitochondria; Bar: $5 \mu \mathrm{m}$. (C) Electron micrograph of a preantral follicle cultured for seven days in $\alpha-M E M+$ (cultured control). Note the vacuolization and the great holes present in the cytoplasm, indicative of degeneration. $\mathrm{O}$; oocyte; GC: granulosa cells; N: nucleus of granulosa cells; V: vacuole; *empty area in ooplasm (probably formed by fusion of vacuoles); Bar: $5 \mu \mathrm{m}$. 


\section{DISCUSSION}

The present study demonstrated for the first time the effects of TGF- $\beta$ in different concentrations on goat preantral follicle survival, activation and growth during seven days of culture. Moreover, the preantral follicle survival verified in cultured ovarian tissues by histological analysis was further confirmed by ultrastructural analysis. It is noteworthy that the concentrations of TGF- $\beta$ used in this experiment were chosen based on the previous studies performed with this factor in other species, since TGF- $\beta$ has never been tested in in vitro culture of goat preantral follicles.

In this study, the ultrastructural analysis showed that $\alpha-\mathrm{MEM}^{+}$was not capable of maintaining the normal ultrastructure of preantral follicles. Conversely, TGF- $\beta$ at $10 \mathrm{ng} / \mathrm{mL}$ maintained the ultrastructural integrity of the follicles after seven days culture. In fact, we observed that, similar to the fresh control, follicles grown in the presence of $10 \mathrm{ng} / \mathrm{mL}$ TGF- $\beta$ preserved important structures, such as mitochondria, endoplasmic reticulum and granulosa cells, as well as basement and nuclear membranes. According to Matos et al. (2007), the ultrastructural analysis is an efficient method for the fine study of the ovarian follicle morphodynamics, and can be considered an essential tool in the evaluation of follicular quality after in vitro culture.

With respect to the TGF- $\beta$ actions on thefollicular development, in the present study although TGF- $\beta$ had no effects on the activation of preantral follicles and oocyte growth, after one and seven days of culture, a significant increase in follicle diameter was observed after using a medium containing $10 \mathrm{ng} / \mathrm{mL}$. It is well known that folliculogenesis is controlled by complex interactions between endocrine, paracrine, and autocrine factors. The outcome of follicular development is therefore dependent on the fine balance between stimulatory and inhibitory factors within the ovary. Overall, the results from the present study as well as those from other in vitro studies in goats (for review see- Figueiredo et al., 2011) confirm this statement since most of the substances tested had positive or negative effects on follicular development depending on the concentrations and combinations used. Likewise, positive (murine: Roberts and Skinner, 1991; Roy, 1993) and negative (murine: Rosairo et al., 2008) effects of TGF- $\beta$ on in vitro folliculogenesis have been reported. Similar to our results, Arunakumariet al. (2010) showed that TGF- $\beta$ also at $10 \mathrm{ng} / \mathrm{mL}$ stimulated the growth of isolated sheep preantral follicles. Such effect on follicle growth may be due to the fact that TGF- $\beta$, in a dose dependent manner, induced follicular DNA synthesis (hamster; Roy, 1993).

\section{CONCLUSIONS}

In conclusion, TGF- $\beta$ at $10 \mathrm{ng} / \mathrm{mL}$ had a positive effect on the growth and maintenance of ultrastructural integrity of goat preantral follicles enclosed in ovarian tissue during seven days of culture.

\section{ACKNOWLEDGMENTS}

This work was supported by the National Council for Scientific and Technological Development (CNPq, Brazil, grant number: 474731/2007-3), Coordination for the Improvement of Higher Education Personnel (CAPES) and Brazilian Innovation Agency (FINEP). Giovanna Quintino Rodrigues is a recipient of a grant from $\mathrm{CNPq}$.

\section{REFERENCES}

ARUNAKUMARI, G.; SHANMUGASUNDARAM, N.; RAO, V.H. Development of morulae from the oocytes of cultured sheep preantral follicles. Theriogenology, v.74, p. 884-894, 2010.

CELESTINO, J.J.H.; LIMA-VERDE, I.B.; BRUNO, J.B. et al. Steady-state level of bone morphogenetic protein-15 in goat ovaries and its influence on in vitro development and survival of preantral follicles. Mol. Cell. Endocr., v.338, p.19, 2011

ER-LIN, L.; XIN-HUA, X.; YE-FEN, X. et al. Relationship between the mRNA expression level of TGF-b receptor genes in tissues and ovulation rate in Hu sheep. Agricul. Sci. China., v.9, p.1659-1666, 2010.

FIGUEIREDO, J.R.; CELESTINO, J.J.H.; FAUSTINO, L.R.; RODRIGUES, A.P.R. In vitro culture of caprine preantral follicles: Advances, limitations and prospects. Small Rumin Res, v.98, p.192-195, 2011. 
HERNANDEZ, E.R.; HURWITZ, A.; PAYNE, D.W. et al. Transforming growth factor- $\beta 1$ inhibits ovarian androgen production: gene expression, cellular localization, mechanisms(s), and site(s) of action. Endocrinology, v.127, p.2804-2811, 1990.

KNIGHT, P.G.; GLISTER, C. TGF- $\beta$ superfamily members and ovarian follicle development. Reproduction, v.132, p.191-206, 2006.

MATOS, M.H.T.; SILVA, J.R.V.; RODRIGUES, A.P.R.; FIGUEIREDO, J.R. Técnicas para avaliação da qualidade de folículos ovarianos pré-antrais cultivados in vitro. Rev. Bras. Reprod. Anim., v.31, p.433-442, 2007.

ROBERTS, A.J.; SKINNER, M.K. Transforming growth factor-alpha and -beta differentially regulate growth and steroidogenesis of bovine thecal cells during antral follicle development. Endocrinology, v.129, p.2041-2048, 1991.

ROSAIRO, D.; KUYZNIEREWICZ, I.; FINDLAY, J.; DRUMMOND, A. Transforming growth factor$\beta$ : its role in ovarian follicle development. Reproduction, v.136, p.799-809, 2008.
ROY, S.K. Epidermal growth factor and transforming growth factor-beta modulation of follicle-stimulating hormoneinduced deoxyribonucleic acid synthesis in hamster pre-antral and early antral follicles. Biol. Reprod., v.48, p.552-557, 1993.

SHARMA, G.T.; DUBEY, P.K.; KUMAR, G.S. Effects of IGF-1, TGF- $\beta$ plus TGF- $\alpha$ and bFGF on in vitro survival, growth and apoptosis in FSH-stimulated buffalo (Bubalis bubalus) preantral follicles. Growth Horm. IGF Res., v.20, p.319-325, 2010.

ZHENG, X.; PRICE, C.A.; TREMBLAY, Y. et $a l$. Role of transforming growth factor- $\beta 1$ in gene expression and activity of estradiol and progesterone-generating enzymes in FSHstimulated bovine granulosa cells. Reproduction., v.136, p.447-457, 2008. 